\title{
PRÁCTICAS TEXTILES PARA SUBVERTIR LOS ESPACIOS PÚBLICOS. \\ DEL SUFRAGISMO AL CONTRA-FEMINICIDIO'.
}

\author{
TEXTILE PRACTICES TO SUBVERT PUBLIC SPACES.
}

FROM WOMEN'S SUFFRAGE TO ANTI-FEMICIDE MOVEMENTS

\author{
Belén Ruiz Garrido \\ Universidad de Málaga
}

\section{RESUMEN}

El presente trabajo pretende rastrear las huellas de las prácticas textiles realizadas por las mujeres y su potencial transformador como herramientas reivindicativas en los espacios públicos, y valorarlas como intervenciones estético-políticas. Encontramos un hilo conductor que vincula de forma sorprendente las experiencias activistas de las sufragistas británicas y diversas acciones de movimientos contra el feminicidio contemporáneo. Abordar estas cuestiones presupone tratar aspectos de partida que atañen a los cimientos de la institución arte y la jerarquización de los géneros, las técnicas y los formatos; también a los relatos histórico-artísticos con pretensiones universales. Los estudios feministas han desentrañado el carácter construido de categorías tales como canon o genio creador, y de la propia definición y delimitación de lo artístico. Y han desenmascarado las barreras construidas entre lo público y lo privado, que atañe directamente a la estimación historiográfica de las labores textiles.

Palabras Clave: prácticas textiles, intervenciones estético-políticas, sufragistas británicas, feminicidio, espacio público.

\section{ABSTRACT}

The objectives of this work are to trace the development of women's textile practices and their transformational potential as tools to express protest in public spaces, and to evaluate these practices as aesthetic-political interventions. We find a common thread that surprisingly links the activist experiences of British suffragettes to various actions of contemporary anti-femicide movements. Tackling such issues implies dealing with basic aspects related to the foundations of the institution of art and the development

1 Este trabajo forma parte del Proyecto I+D «Prácticas de subjetividad en las artes contemporáneas. Recepción crítica y ficciones de la identidad desde la perspectiva de género» (HAR2016-75662-P). Ministerio de Economía y Competitividad, $2016-2020$. 
of hierarchies in gender, techniques and formats, in addition to historical-artistic narratives with claims to universality. Feminist studies have unravelled the constructed nature of categories such as canon or creative genius, and the very definition and limits of what constitutes the artistic. They have also revealed the barriers erected between public and private life, which has a direct relevance for the historiographical consideration accorded to textile practices.

Keywords: Textile Practices, Aesthetic-Political Interventions, British Suffragettes, Femicide, Public Spaces.

\section{SUMARIO}

1.-Hilos y puntadas desde el sufragismo al contra-feminicidio. Deconstruyendo cánones. 2.- La revolución de los delantales, los pañuelos y la indumentaria. Del ámbito doméstico a la conquista del espacio público. 3.- Bordar contra el feminicidio. 4.- Referencias y bibliografía.

\section{Hilos y puntadas desde el sufragismo al contra-feminicidio. Deconstruyendo cánones}

Acercarnos a las prácticas textiles realizadas por mujeres compone lo que podríamos calificar como un «mapa de presencias y huellas». Porque en ocasiones se trata de reconocer presencias y rastrear huellas, en relación a la pluralidad de sus perfiles. Esta diversidad tiene que ver con el carácter heterogéneo del uso del tejido y las labores asociadas a las mujeres mediante algunas de las vías de su potencial. Todos los hilos y las puntadas constituyen el tejido, pero este es susceptible de configurarse en distintas direcciones, extensiones y formas. Algunos de los asuntos relacionados con la disponibilidad y maleabilidad del uso del tejido y las labores asociadas a su fabricación por las mujeres son: la profesionalización artística, su visibilidad y reconocimiento, el uso subversivo y político, los trasvases y retroalimentaciones entre esferas vitales tales como lo domésticoprivado-público, o entre sus espacios asociados, la casa y la ciudad, y la capacidad de incidencia e intervención en la esfera pública, o en las aptitudes relacionales que tienen que ver con la reafirmación individual y colectiva.

Un breve recorrido por las creaciones artísticas desde la Antigüedad muestra el alto interés por la representación de mujeres realizando labores textiles de todo tipo. Tanto es así que podría constituir un asunto con entidad iconográfica. En escenas domésticas, en entornos industriales, en las fábricas, como trabajadoras y operarias, en contextos de realidad social o costumbristas, o bien idealizadas, hilando, cosiendo, bordando, como elementos sublimados en las alegorías o como musas inspiradoras de la acción creadora, las mujeres han sido tratadas como objetos observados y recreados en las imágenes. 
Sin embargo, una mirada histórica sobre el desempeño de todo tipo de actividades relacionadas con el textil por parte de las mujeres muestra una asociación continua, pero al mismo tiempo fluctuante en su visibilidad y reconocimiento. Se tiene constancia de esta dedicación femenina en todas las culturas y civilizaciones.

Partiendo de planteamientos feministas que resitúan la consideración de las labores femeninas en el seno de la economía, la sociedad y la cultura griegas, Marina Picazo (2008: 95-1 18), refiere que en la Grecia antigua cuando se hablaba de «trabajos de las mujeres», no se hacía referencia a las tareas domésticas en general, sino a las relacionadas con la elaboración de tejidos. Estas labores, dentro de las llamadas «actividades de mantenimiento», eran imprescindibles para el funcionamiento de la comunidad, además de suponer el dominio de unos conocimientos tecnológicos de gran especialización, contribuir a la economía doméstica, ser portadoras de una profunda carga significativa y simbólica -recordemos que la diosa Atenea era agasajada con un peplo tejido por jóvenes doncellas pertenecientes a las familias más reconocidas de la ciudad y que las mujeres eran las encargadas de confeccionar el ajuar textil necesario para celebrar todos los actos trascendentales para la vida y la muerte de los miembros de la familia- y formar parte de los procesos de sociabilidad y reconocimiento entre las mujeres. $Y$ esto a pesar de la baja estima masculina de estas labores y de la recomendación de su ejercicio en la construcción de un ideal de feminidad decoroso, supeditado y sumiso por el control patriarcal.

Asimismo, Witney Chadwick coloca la problemática de la autoría y la jerarquización de las artes en el centro del debate sobre el trabajo textil-artesanal en la Edad Media y su interpretación por la historiografía decimonónica. La trascendencia histórica, artística y simbólica de una pieza bordada como el tapiz de Bayeux, del siglo Xl, debía ser equiparada con grandes nombres. De ahí que las manos de la reina Matilda se conviertan en las aristocráticas ejecutantes de una obra, en ese caso, incompatible con el trabajo artesano, anónimo y colectivo, separado definitivamente de la obra artística. La realidad histórica sitúa su realización bien en talleres de ambos sexos, en opinión de Rosizka Parker, o en monasterios femeninos (1992: 42-43). Se tiene constancia de artesanas sederas, bordadoras, ropavejeras, pañeras, hilanderas, fabricantes de ropa, brocanteras, y más, que trabajaron en talleres, pagando los impuestos correspondientes y recibiendo sus salarios, en la Edad Media.

Es posible que la separación de esferas construidas como antagónicas y asimétricas, entre lo público y lo privado, y las diferenciaciones cualificadas entre lo doméstico, lo aficionado y lo profesional, tengan mucho que ver con el sistema de apropiación indebida impuesto por el proceso capitalista de explotación y producción, como ha estudiado Silvia Federici en Calibán y la bruja (2004). En este proceso, las grandes damnificadas han sido 
las mujeres, cuyos trabajos se consideran subsidiarios, invisibles, manipulables y baratos, mientras que la resistencia y la diferencia han sido demonizadas y penalizadas.

Tratar el tema de la presencia activa de las mujeres en los distintos campos de la actividad textil presupone entonces varios aspectos de partida teóricos y metodológicos. Por un lado, los planteamientos que atañen a la consideración de los conceptos de «paradigma» y «canon», como claves para descubrir el carácter construido de los relatos históricoartísticos hegemónicos. En este sentido son esenciales, entre otros, el trabajo de Rozsika Parker y Griselda Pollock, Old Mistresses: Women, Art and Ideology (1981) y los de G. Pollock, Visión y Diferencia. Feminismo, feminidad e historias del arte (1988) y Differencing the Canon: Feminist Desire and the Wrting of Art's Histories (1999) ${ }^{3}$. Las intervenciones feministas en la historia del arte que van más allá del ejercicio de recuperación de nombres y su incorporación a los relatos ya construidos implican, en palabras de Pollock, «cambiar de paradigma», que es «algo más que tan solo agregar nuevos materiales -las mujeres y su historia- a las categorías y métodos ya existentes: nos ha llevado a maneras completamente nuevas de conceptualizar lo que estudiamos y el modo cómo lo estudiamos» (2013: 27). Esto supone desvelar que el canon se construye bajo una posición ideológica de poder centrada en los valores dominantes de un sexo -masculino-, clase, y raza dominante, que se presentan como naturales, universales e incuestionables. Por tanto, para Pollock, «el feminismo encuentra el canon como una estructura de exclusión», "como una estructura de subordinación y dominio que margina y relativiza a todas las mujeres de acuerdo con su lugar en las estructuras contradictorias del poder -raza, género, clase y sexualidad» y «como una estrategia discursiva en la producción y reproducción de diferencia sexual» (1999, 2007: 143-158).

En la misma base de la visibilización de la condición construida del canon, las lecturas de género han desvelado la construcción de categorías como la del genio, y la clasificación jerárquica de arte y artesanía, o alta y baja cultura, además de la propia definición de arte. Siguiendo a Pollock, M. Antonietta Trasforini plantea el carácter estereotipado atribuido a la figura del artista, «como genio creador, como persona especial y héroe solitario, enfatizando su individualismo y la unicidad en la producción de la obra» (2009: 43-44), advirtiendo que «como otras categorías abstractas universales, está en realidad determinado por muchas pertenencias: de género, generacionales, geográficas, religiosas» (2009: 44). La autora denuncia que:

2 Principalmente el capítulo 2: Crafty women and the hierarchy of the arts.

3 Traducción de una parte del capítulo «Diferenciando: el encuentro del feminismo con el canon», en Cordero y Sáenz (comps.), 2007: 141-158) 
el estereotipo más indigno que recorre la historia del arte y que se refuerza en el XIX es el que, siendo obviamente negativo, representa a las mujeres como carentes de creatividad, incapaces de contribuciones e influencias significativas en el campo artístico. Este estereotipo homogeneiza su trabajo como si estuviera completamente determinado por un género natural, negando su heterogeneidad, la diversidad y, por lo tanto, la especificidad de su producción y de su obra; pero también se reconoce lo que las mujeres comparten y que es el resultado no de la naturaleza sino de la cultura, esto es, de los sistemas sociales que históricamente han producido y producen diferencia sexual, es decir, género (2009: 46).

Los estudios de género también han puesto en evidencia que las estructuras jerárquicas de los géneros artísticos, los soportes y las formas, forman parte también de la concepción del canon, es decir, es una cuestión que se relaciona con la construcción social de lo masculino y lo femenino. De ahí que haya temáticas, estudios y materias que se pretenden naturalmente consustanciales a la feminidad. Recuerda Trasforini que las distinciones a todos los niveles -académicas, discursivas, disciplinarias- entre arte y artesanía, y por extensión entre artes mayores y menores, se había iniciado en el Renacimiento, pero se ve reforzado en los siglos XVIII y XIX.

Desarrollándose sobre líneas de clase y sobre contraposiciones de género, esto se convierte en un mecanismo que ha producido -y sigue produciendo- diferenciación social, estratificación y desigualdad en la posesión y el uso de capital simbólico. Para Parker y Pollock (1981), la distinción entre artista y artesano es un asunto económico y social, pero particularmente en el siglo XIX se reforzará con la atribución distintiva de las habilidades entre hombres y mujeres. Desde luego este discurso ya se encuentra en la literatura clásica, pero es en el siglo decimonónico cuando encontrará incluso una justificación «científica», como ha estudiado Bram Dijkstra (1986). De esta manera el arte se relacionará con el talento y la creatividad, que es capaz de crear objetos únicos, significativos y trascendentes, mientras que la artesanía lo estará con la habilidad de crear objetos útiles siguiendo unos conocimientos técnicos que se pueden adquirir con formación. El reparto de talentos y habilidades no es ajeno al género, remite a él y reproduce su disparidad. Parker y Pollock (1981) perfilan aún más este asunto al desvelar que la creación también está indisolublemente vinculada al estatus de quien la ha practicado y al lugar social en el que se ha realizado:

...lo que distingue jerárquicamente el arte de la artesanía no son tanto los diferentes métodos, prácticas y objetos sino también dónde se han hecho estas cosas -con frecuencia en casa- y para quién se hace -con frecuencia para la familia-. Puesto que el arte (the fine arf) es una actividad pública, profesional, lo que hacen las mujeres -y que habitualmente se define como artesanía- podría definirse como arte doméstico (cit. Trasforini, 2009: 50). 
A este respecto es significativo el caso que recogen Parker y Pollock (1981), y que refiere igualmente Trasforini (2009), sobre la necesidad que manifestó un crítico de arte de pensar que los tejidos realizados por mujeres navajo, que estaba contemplando, eran cuadros pintados por maestros de la abstracción desconocidos.

Estas estrategias desvelan significativamente la exclusión en el canon de las prácticas textiles y la cerámica. Desde la década de los setenta, la historiografía feminista está descubriendo, de forma crítica, el carácter jerárquico construido de la producción artística y sus elementos definidores; recoge Pollock esta reflexión de Patricia Mainardi:

Las mujeres siempre han hecho arte. Pero para las mujeres, las artes más valoradas por la sociedad masculina han permanecido cerradas precisamente por esa razón. Ellas entonces han aplicado su creatividad en las artes de la costura, las cuales existen en una variedad fantástica, y son de hecho una forma de arte femenino universal que trasciende raza, clase y fronteras nacionales. La costura era el único arte mediante el que las mujeres controlaban la educación de sus hijas y la producción del arte, y donde eran también la crítica y el público [...] es nuestra herencia cultural $(1999,2007$ : 144).

El feminismo plantea entonces no solo el profundo valor cultural de los textiles sino también su potencial como productores de significados religiosos, políticos, morales e ideológicos (Pollock, 1999, 2007: 144; Parker, 1984). Si bien Pollock advierte del peligro de realizar una simple traslación para insertarse, desde la otredad, en el relato canónico, únicamente «interrumpiendo la historia del arte» $y$, por tanto, convertirse en una mera reivindicación esencialista -«meras instancias de diferencia» lo denomina la autora (1999, 2007: 144)-, sin proyección ni capacidad política subversiva, no cabe duda de que la toma de conciencia, el cuestionamiento y la revelación contienen en sí ese potencial para accionarlo.

Por ello rastrear las huellas del trabajo textil y su potencial político, como herramientas reivindicativas útiles en los espacios públicos con efectos transformadores, se sitúa en el seno del discurso teórico que cuestiona qué es y qué no es arte, quién lo define y a quiénes cualifica como tales. El objetivo es desarticular el canon visibilizando y valorando el trabajo de las mujeres en estas labores del tejido, rastreando sus capacidades creativas como colectivo, perfilando sus características, planteando su escasa valoración como sujetos y la abundancia de sus representaciones como objetos recreados.

Lo «público» está cualificado como «conocido, notorio, manifiesto y divulgado» y, por extensión, «oficial, estatal, gubernativo, administrativo»; pero también hace referencia a «auditorio, concurrencia, asistencia, espectadores, oyentes». Mientras que «publicar» 
conlleva las capacidades de «avisar, transmitir, divulgar o revelar». Su esfera antónima se define como «privada y secreta», es decir, «íntimo, individual, reservado, personal y particular»; y, además, en la negatividad de lo «falto, carente, desprovisto, despojado, desposeído». En relación al espacio y al carácter de lo realizado, lo doméstico implica al ámbito "casero, hogareño, familiar» y en su dimensión actitudinal o psicosocial, las atribuciones de «mansedumbre, docilidad y sumisión»; la acción de domesticar supone «amaestrar, amansar, domar, someter, dominar». En una comprensión binaria, polarizada y jerarquizada de la realidad y sus componentes vitales y culturales, esta caracterización de lo doméstico y lo público se adscribe en oposición sexualizada, masculina y femenina, presentando sus espacios correspondientes en confrontación, impenetrables e intransferibles. De ahí que las acciones encaminadas a romper estas barreras -entendidas como naturales y esenciales- se presenten como subversivas, independientemente de los efectos políticos transformadores reales.

Percibimos que ese mapa de presencias y huellas se configura con el rastreo de las conexiones que redescubren un interés renovado por las acciones y actividades de las mujeres sufragistas en pos de la consecución de derechos fundamentales. Este hallazgo suscita traslaciones sumamente interesantes, hasta las intervenciones performáticas de los colectivos y activistas contra el feminicidio actuales, es decir, desde principios del siglo XX al siglo XXI, y desde posiciones y objetivos diferentes entre sí, aunque susceptibles de conexión. Las actividades textiles realizadas en los espacios privados y/o públicos por las mujeres sufragistas y los colectivos en lucha contra el feminicidio, se presentan como herramientas de significación, visibilización, autodeterminación, resistencia, reivindicación y protesta, e incluso de eficacia terapéutica. Y suscitan la tesitura de repensar la cualificación de las esferas vitales separadas, así como la reasignación y reapropiación de los ámbitos públicos como lugares propios, necesariamente feminizados y seguros, donde se permitan contaminaciones desde lo particular, personal o privado.

Habría que valorar el alcance y carácter múltiple de esta producción en la formación de una conciencia crítica ${ }^{4}$. No solo ponderar el poder subversivo de lo aparentemente insignificante e intrascendente, sino poner en cuestión la propia calificación de la insignificancia y la intrascendencia. Lanzar pañuelos en lugar de bombas, utilizar agujas en lugar de bayonetas. El activismo de las mujeres en causas feministas, pacifistas y de diverso signo reivindicativo que utilizan «armas» textiles tiene un amplio recorrido. El hilo conductor hilvana las acciones realizadas con crochet en el seno de la Womanhouse, organizada por

4 Resulta significativo que en Nueva crítica feminista de arte. Estrategias críticas, Katy Deepwell, su editora, dedique un apartado expreso a los tejidos y a una revisión de las apuestas expositivas de los ochenta. 
Judy Chicago y Miriam Schapiro, como cofundadoras del programa de arte feminista del California Institute of the Arts (CalArts). También la creativa relación entre el activismo pacifista y las labores textiles en el Greenham Common Women's Peace Camp (Campamento pacifista de mujeres de Greenham Common en Berkshire, Inglaterra), creado en 1981 por un grupo de mujeres galesas para protestar contra las armas nucleares; la experiencia transformó la valla de separación de la base militar en un soporte de sus labores de bordado y costura.

Será necesario dedicar una mirada feminista a otros tipos de conflictos; en ellos las mujeres de nuevo hacen de sus cuerpos auténticos campos de batalla en aras de un activismo consciente en las luchas sufragistas y contra el feminicidio. Muchas de las acciones emprendidas desde estos dos frentes encuentran puntos de contacto en prácticas artísticas de distinto signo. Este último aspecto ha abierto un campo de investigación estimulante y complejo. Tanto las luchas sufragistas como las acciones en contra del feminicidio aúnan de forma colectiva a mujeres que emplean medios y formatos artísticos en pos de la consecución de derechos fundamentales como personas y ciudadanas, y como denuncia de actos criminales contra las mujeres, por el hecho de nacer mujeres, y porque en ellas se encarnan los pilares que sostienen las estructuras de convivencia y la paz social, de ahí su conversión en objetivos a socavar por la óptica patriarcal y misógina.

\section{La revolución de los delantales, los pañuelos y la indumentaria. Del ámbito doméstico a la conquista del espacio público}

Si partimos del cuestionamiento por parte de los estudios feministas de las categorías sacrosantas vinculadas y definitorias de «Arte», tales como artista, genio, calidad, obra única, arte o artesanía, alta y baja cultura, para deconstruir cánones, dinamitar la propia categoría de canon, desfigurando límites y fronteras, se puede apreciar la labor de las activistas que sin ser artistas, ni pretender serlo, emplearon mecanismos y herramientas creativas en aras de una reivindicación personal y política. "Your body is a battleground», la consigna incorporada por Barbara Kruger en la obra de este modo conocida (1989), quizás una de las más beligerantes y significativas del movimiento feminista, había sido puesta en práctica por las sufragistas británicas desde las primeras décadas del siglo XX. Y lo hicieron a través de transformaciones, acciones, intervenciones en el espacio público, un utillaje artístico riquísimo y sus propios cuerpos. Porque, como afirma Toby Clark:

...la propaganda en el arte no siempre es inherente a la imagen misma y puede no derivarse de las intenciones del artista. Aún más, el arte puede convertir en propaganda a través de su función y emplazamiento, su entorno (espacios públicos o privados) y su relación con 
un entramado de objetos y acciones de otro tipo. Los medios para hacer una afirmación ideológica son casi ilimitados: arquitecturas, teatro, música, deportes, indumentaria y cortes de pelo pueden comunicar una visión política, al igual que los espectáculos de violencia, como la quema de libros, el asesinato, el suicidio o el terrorismo (Clark, 2001: 13).

Así las sufragistas británicas habían creado su propio lema conscientes del poder de una frase, años antes de que la publicidad codificara un lenguaje y unas fórmulas específicas. «Deeds, not Words» («hechos, no palabras») contenía al mismo tiempo la predisposición a la acción y la exigencia de respuesta a la misma (fig. 1).

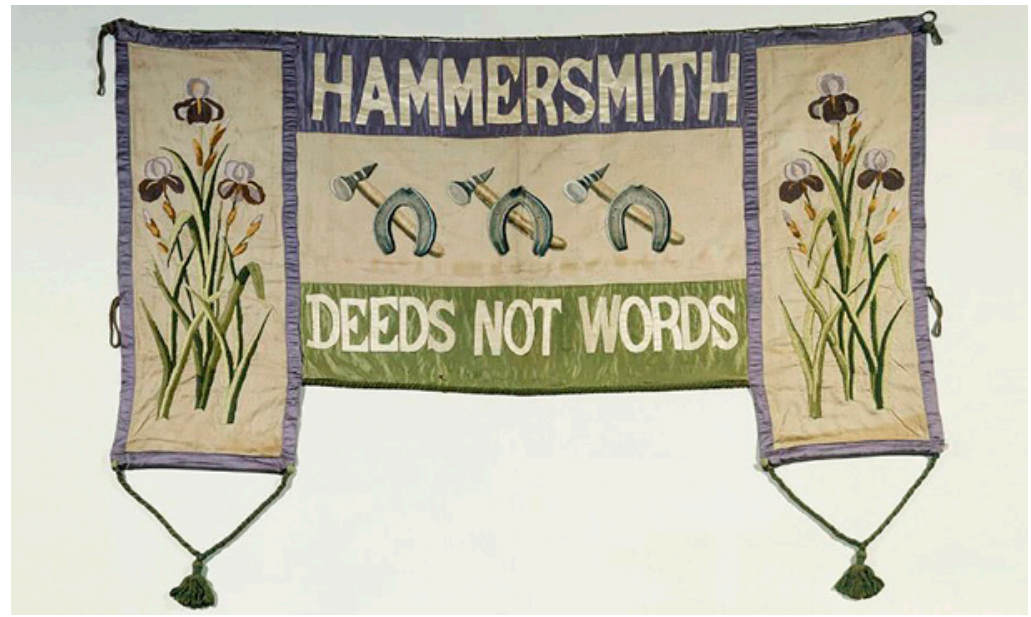

Fig. 1. Bandera de Hammersmith. Women's Social and Political Union (WSPU), h. 1911. Pintura, bordados y aplicaciones. Fuente: Museum of London.

Las sufragistas, por tanto, crearon su propio programa de propaganda subversivo, pacífico o violento, que las identificó, visibilizó eficazmente sus reivindicaciones y dio forma -visual, objetual- a la problemática convertida en lucha, y a sus acciones en campo de batalla. Aunque, en realidad, «estos actos de disidencia deben ser descritos como propaganda de oposición o antipropaganda» (Clark, 2001: 11), puesto que las acciones feministas y sufragistas estaban dirigidas, por un lado, a visibilizar de un modo contundente la problemática para concienciar al mayor público posible, y por otro, y principal, dirigida al Estado y las instituciones encargadas de legislar a favor o en contra de las peticiones. Hablamos de otro tipo de guerra: una guerra que no enfrentaba a los estados por el dominio territorial o ideológico; y de campos de batalla más cercanos: los cuerpos, las casas y las calles. 
En 1903 se había fundado la WSPU (Unión Política y Social de Mujeres), capitaneada por Emmeline Pankhurst, con la participación de sus hijas Christabel y Sylvia. Las militantes combinaron tácticas de muy diversa índole, entre las que estaba la militancia de carácter más agresivo, desplegada con especial virulencia desde 1912. Sus tácticas de guerrilla -ya presentes en la autodenominación como «ejército en el campo de batalla»-se desarrollaron de una forma absolutamente original, inventiva, sorprendente y diversa.

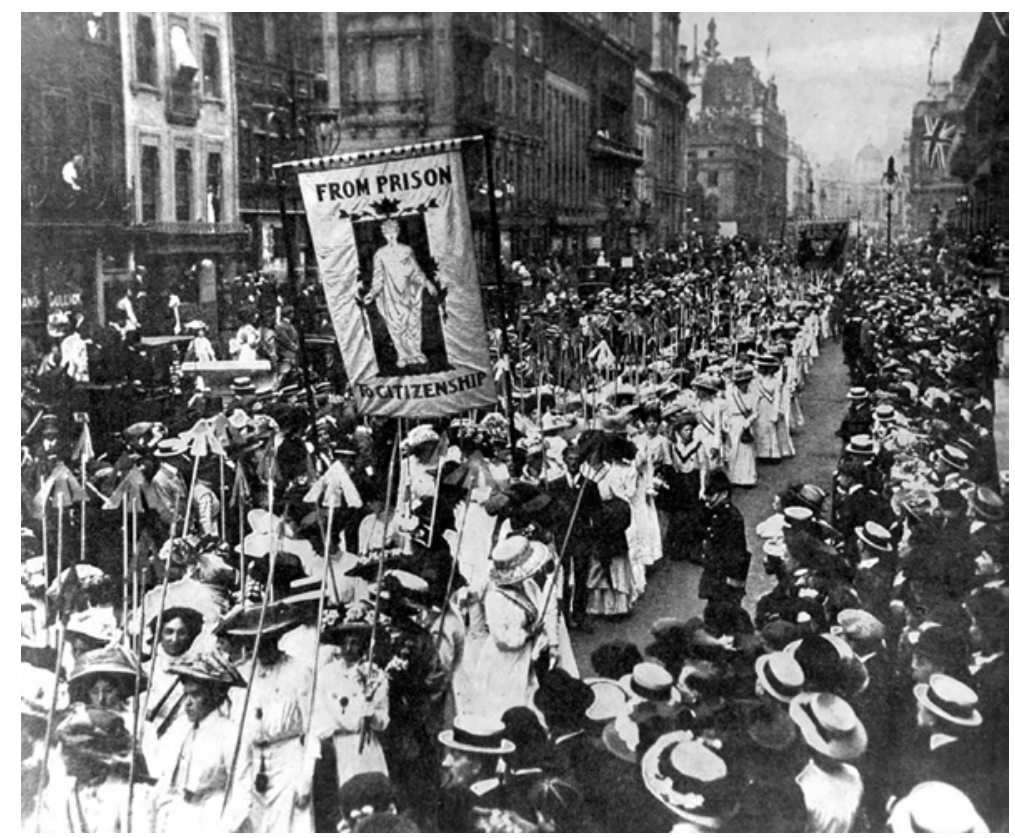

Fig. 2. Manifestación sufragista. Londres, 1910. Fuente: https://www.pinterest.es.

Algunas conscientemente violentas, como la irrupción e interrupción de todo tipo de espectáculos, la rotura de escaparates de comercios con piedras mensajes-campaña de rotura de cristales de marzo de 1912-, incendios y explosiones provocados contra casas de políticos, estaciones de ferrocarril, iglesias y edificios públicos o ataques a obras de arte emblemáticas de los museos; otras pacíficas, como los desfiles y las manifestaciones, en ocasiones multitudinarias (fig. 2), o con final violento por parte de las autoridades y en contra de las manifestantes, como algunos mítines y concentraciones ante instituciones públicas representativas. La visibilización en el espacio público, y su consecuente perturbación, pasó también por imaginativos métodos 
de propaganda y protesta, como la utilización de zepelines para el lanzamiento de panfletos, la pintura y escritura sobre el pavimento y los muros del Parlamento, o la instalación de mostradores de información en las calles (González, 2009: 71-72).

Estas fórmulas de activismo no fueron las únicas. Las sufragistas promovieron una intensa labor creativa vinculada a actividades artísticas de diversa índole, desde el diseño de carteles hasta la creación de todo tipo de joyas y objetos que servirían de soporte reivindicativo y medio de difusión de largo alcance. En este campo del activismo fueron esenciales las labores textiles en su más amplia factura y diversidad, desde la costura, el bordado y las aplicaciones, al diseño y producción de indumentarias y accesorios.

Por esta razón, las labores textiles llevadas a la calle no fueron solo una herramienta. La utilización de estas prácticas y su reconversión en los espacios públicos tenían que ver con un mecanismo consciente de ejercicio subversivo, al colocar en primera línea «cuestiones femeninas» consideradas de «segunda», por su domesticidad o por su falta de profesionalidad, es decir, en los puestos secundarios de las artesanías, aquellos que no tenían que ver con la profesionalización sino con las ocupaciones de mantenimiento y cuidado. Pero además, y como apunta Parker (1984: 189-215), la asociación entre el trabajo textil, concretamente el bordado, y la feminidad no fue un obstáculo para el movimiento sufragista-como sí lo fue para el constructivismo, por ejemplo- sino una oportunidad para cambiar las ideas tradicionales y preconcebidas sobre las mujeres y la feminidad, asociación que potenciaba la fortaleza de las mujeres en aras de desmontar la pretendida debilidad naturalizada.

Quizás las sufragistas no tuvieron entre sus objetivos, al menos de forma consciente o programática, la incidencia transformadora de sus actividades creativas en la «institución arte», para cambiar su lugar y su función (Parker, 1984: 197), aunque no cabe duda de que sus trabajos y sus acciones forman parte del corpus de artefactos culturales y artísticos desestabilizadores del canon. Desde luego, los caminos que se abren con esta lectura son múltiples y trascienden el ámbito de lo textil. Parker (1984) abona el camino para indagar en otra idea que está en la base del trabajo de las mujeres sufragistas. La ausencia de profesionalidad y la libertad no mediatizada por las exigencias de la obra profesional en el uso de materiales, técnicas y soportes, como los bordados o el collage, como prácticas que se sitúan del lado de lo artesanal y hecho a mano, coloca la definición del artista profesional en un lugar cuestionado, pues estas mujeres no lo hacen de forma ingenua sino como verdaderas conocedoras del bordado -al igual que los artistas lo eran de la pintura-, planteando una equiparación en la diferencia. Por ello la dimensión estética del movimiento trascendía el propio objetivo político para suscitar una reflexión que afectaba a la propia institución artística canónica: «conscientemente -ahonda Clark- ignoraron la jerarquía convencional 
que situaba al arte por encima de la artesanía y defendía «la obra maestra intemporal» por encima de cualquier objeto efímero anónimo» (Clark, 2001: 31 ). Es la esencia del trabajo colaborativo, usando métodos artesanales tradicionales, uno de los asuntos más interesantes de analizar. En el ámbito del sufragismo británico, la producción artística de ilustradoras y bordadoras se canalizó a través de empresas artísticas creadas para tal fin. Es el caso del Atelier y la Liga de Artistas Sufragistas (ASL), diferenciadas por la profesionalidad o el voluntarismo de las mujeres miembros (fig. 3).

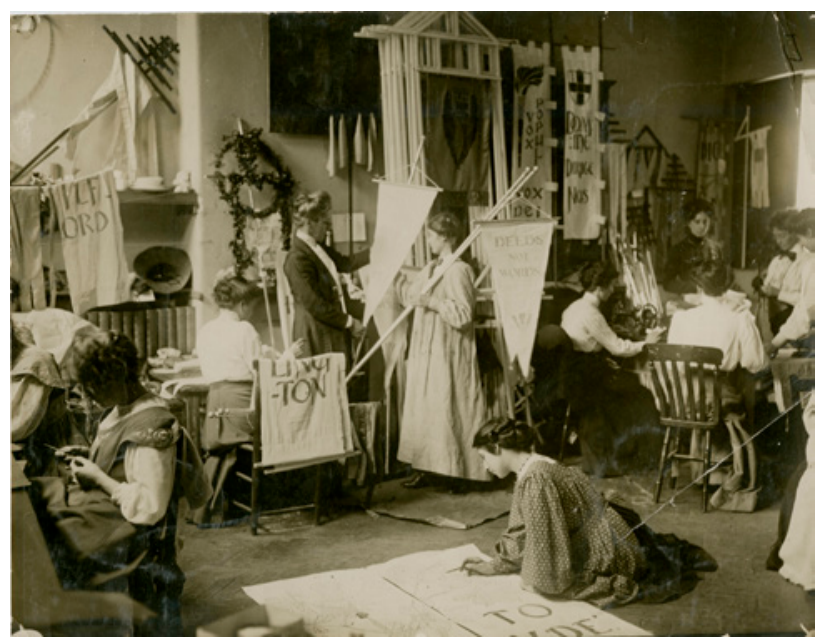

Fig. 3. El taller de la Artists Suffrage League (ASL) Fuente: Museum of London.

Un aspecto de gran interés es que algunas de estas labores consideradas «propias de mujeres» salen del ámbito doméstico para invadir las calles. Desde finales del siglo XIX las mujeres del «ejército en el campo de batalla sufragista» habían utilizado la palabra asociada a sus propios cuerpos desde posiciones menos extremas, como soportes móviles de las reivindicaciones, no solo redactadas estas en pancartas sino portando sus consignas y llamamientos como partes de su indumentaria. Me interesa particularmente el uso de una prenda doméstica, como el delantal, tanto como soporte informativo, como elemento de ruptura entre el espacio de la casa y la calle. Las sufragistas Mabel Capper y Patricia Woodlock fueron fotografiadas con el anuncio de un encuentro a celebrar el 19 de julio de 1908 en Heaton Park, Manchester (fig. 4). Estas activistas colocaron la propaganda impresa en hojas informativas en forma de delantal sobre sus faldas. Conscientemente la falda o el 154 delantal evidenciaban sus condiciones, femenina y doméstica, reasignadas en sus cometidos. 


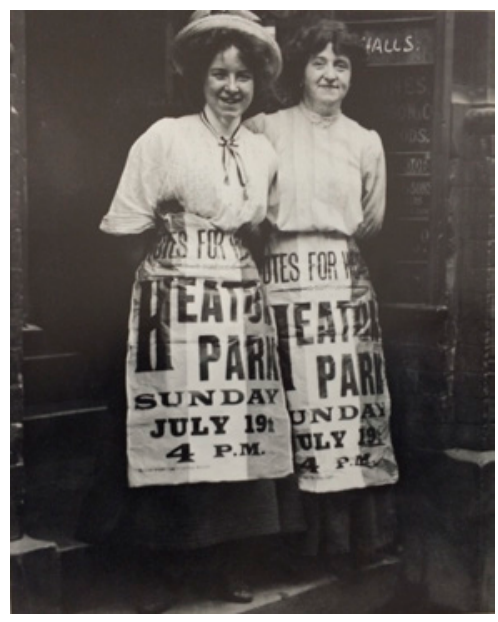

Fig. 4. Mabel Capper y Patricia Woodlock, 1908. Fuente: https://www.pinterest.es.

Un acto aparentemente inocente e incluso divertido como este -las dos mujeres, jóvenes y espontáneas, se muestran sonrientes y decididas frente a la cámara, validando el poder de convicción y convocatoria que desplegaban las activistas- no debía ser tomado a la ligera por las instituciones públicas garantes del orden moral y social. La propaganda antisufragista, tan copiosa y beligerante contra las peticiones políticas femeninas, consideraba a estas mujeres, y lo que representaban, una verdadera amenaza para el statu quo, defensor de la moralidad y la normalidad de los roles de género. En esta propaganda no es casual encontrar referencias a la inversión de papeles en el hogar, peligrosa incluso por conllevar una desestabilización de la virilidad y la feminidad entendidas como naturalezas esenciales. En ella a menudo aparece el esposo y padre de familia realizando labores domésticas, al margen por tanto de su cometido social y «natural», ante el abandono de su esposa sufragista, ocupada en menesteres «antinaturales», con el consiguiente perjuicio para el hogar familiar, convertido en un lugar infernal por culpa de la dejación de funciones de estas féminas invertidas. Debía quedar clara la advertencia, de hecho, la propaganda antisufragista no tenía un carácter únicamente jocoso o grotesco, sino que a través de este lenguaje podía contrarrestar, y ese era su cometido, la ofensiva subversiva ${ }^{5}$. El ejercicio de actividades, asignadas tradicional y naturalmente masculinas, por parte de las sufragistas, no solo suponía una usurpación de funciones ajenas, sino que podía

5 El amplio contexto y significación de la imaginería antisufragista en Tickner (1987) y Nead (1998), esta última a propósito del ataque de la sufragista Mary Richardson a la Venus del espejo de Velázquez. 
provocar inversiones morales e incluso físicas en los hogares afectados. Por supuesto, entre las labores invertidas no puede faltar la actividad textil que aparece en muchas de estas imágenes, donde los hombres hacen calceta o zurcen calcetines, mientras sostienen a bebés inconsolables, mientras la esposa lee un periódico deportivo y fuma (fig. 5).

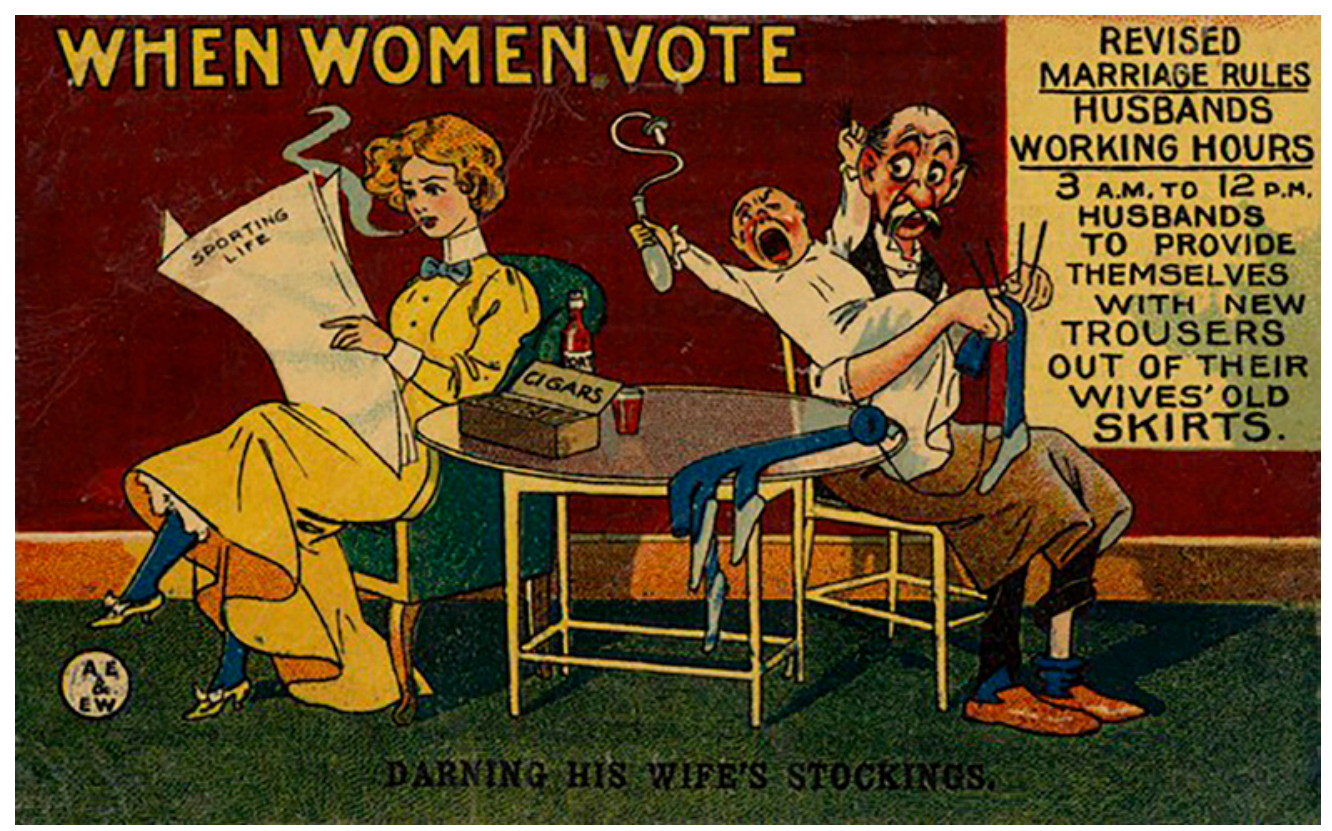

Fig. 5. When Women Vote. Cartel antisufragista. Fuente: Look and Learn / Elgar Collection.

En contraposición, la pintura y la fotografía ofrecían imágenes de corrección idealizada donde las labores textiles presuponían un mantenimiento del orden lógico de las cosas, en distintas asociaciones de ideas: como fórmula de unión y aprendizaje de la maternidad o como indicios de un hogar burgués ejemplar. Incluso la reina Victoria aparece fotografiada haciendo crochet, porque solo una reina es aceptada como tal, y puede actuar como ejemplo, si esta circunstancia se presenta compatible con su ser femenino, dotado esencialmente para la maternidad y sus labores asociadas. Las sufragistas también fueron fotografiadas realizando labores de costura en la prisión (fig. 6).

El papel de la indumentaria auto-diseñada y auto-confeccionada, en la creación de la imagen de la mujer sufragista, supuso entonces un ejercicio programático de identificación 
y significación públicos, pero también de reconocimiento entre ellas como colectivo. Efectivamente, la indumentaria «confirió al movimiento una coherencia visual y se sirvió de la moda como un medio de afirmación ideológica» (Clark, 2001: 31). Es sumamente interesante, dado el poder de estas capacidades y usos transformadores de las ciudades y sus espacios. Sin dejar nada al azar, todos los accesorios de moda femeninos fueron susceptibles de componer el corpus uniformado sufragista, como soportes y prendas reconocibles: los espacios públicos redefinidos 0 recalificados en femenino se llenaban de mujeres claramente identificadas que, en sus paseos, marchas, manifestaciones, puestos informativos y mítines, portaban sombrillas, pamelas, banderolas, bufandas, cinturones, bolsos y broches con los lemas reivindicatorios.

Para la construcción propagandística e identificatoria de la imagen sufragista fueron determinantes los colores. Los denominados colores sufragistas, el violeta, el blanco y el verde, se aplicaron a toda la producción textil-además de al diseño de todo tipo de objetos y material impresos-, creando una verdadera «marca sufragista» en una operación de marketing sin precedentes. El atuendo sufragista, consensuado en 1908, postulaba también el blanco como el color adecuado, en relación al tipo de telas apropiadas al invierno y al verano. Además de las asociaciones simbólicas ${ }^{6}$, las sufragistas buscaban la practicidad y

6 Emmeline Pethick Lawrence, una de las fundadoras de la WSPU, popularizó los tres colores del movimiento feminista. En el periódico fundado junto a su marido, Votes for women, verdadero órgano de difusión del movimiento, se publicó en 1908 el carácter simbólico de estos colores: «El violeta, color de los soberanos, simboliza la sangre real que corre por las venas de cada luchadora por el derecho al voto, simboliza su conciencia de la libertad y la dignidad. El blanco simboliza la honradez en la vida privada y en la vida política. Y el verde simboliza la esperanza en un nuevo comienzo».

Recuperado de https://trinitycollegelibrarycambridge.wordpress.com/tag/emmeline-pethick-lawrence/. Con esta adopción, además, el sufragismo seguía la práctica común iniciada en la Revolución Francesa que asociaba las banderas tricolores a los movimientos liberadores.

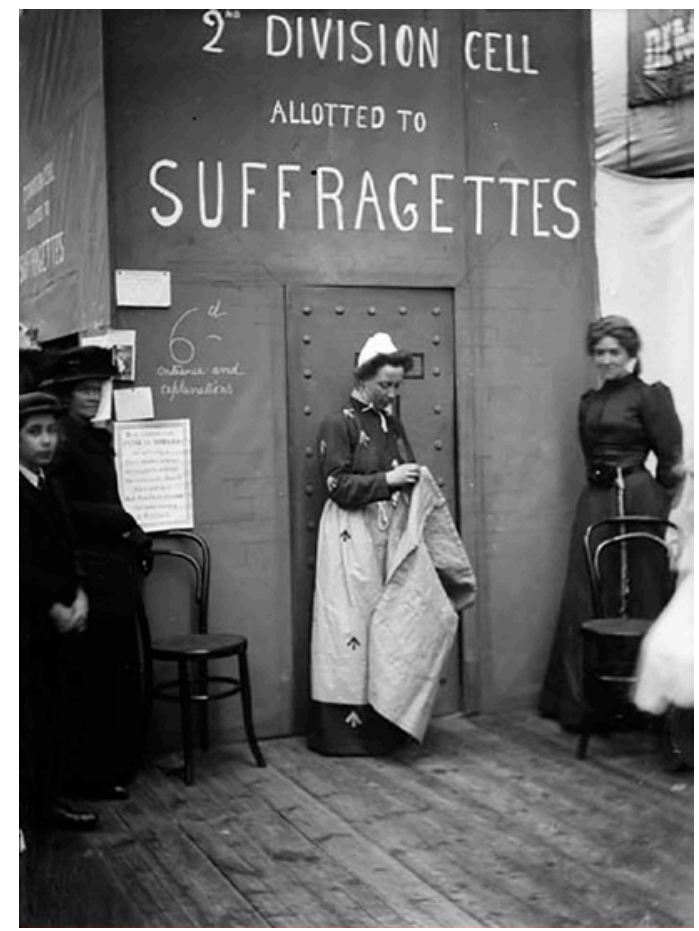

Fig. 6. Sufragista en prisión. Fotografía de Christina of London. Broom. The Women's Exhibition, 1909. Fuente: Museum 
economía que otorgaban los colores básicos, la sencillez y austeridad en el vestir y una atención a la feminidad que se estaba poniendo en duda. Pero, además, en las concentraciones y manifestaciones, se lograba un sorprendente efecto colectivo, un auténtico «ejército», tiñendo de blanco las calles, plazas y parques de las ciudades, salpicadas de los colores violetas y verdes aplicados a todo tipo de material propagandístico confeccionado con tejidos bordados y aplicaciones (fig. 7).

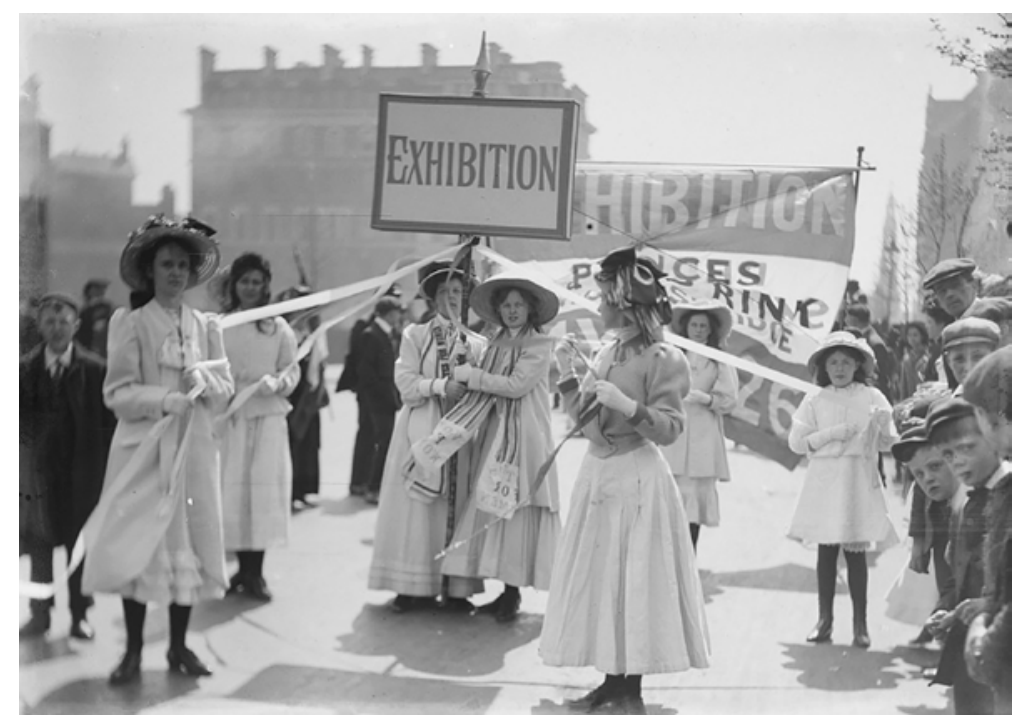

Fig. 7. Jóvenes sufragistas promocionando The Women's Exhibition, 1909. Fotografía de Christina Broom. Fuente: Museum of London.

Las asociaciones bélicas manejadas por el activismo sufragista llevadas al ámbito de la indumentaria se desplegaron asimismo en otro tipo de uniformes más específicos, y en general, vinculados a personalidades dentro del propio movimiento. Es el caso de la identificación militar de Flora Drummond, apodada «la generala», mediante su uniforme, al parecer, donado por una fábrica de insignias para la manifestación Women's Sunday del 21 de junio de 1908. Este uniforme recuerda, según Clark, al de las mujeres del Ejército de Salvación, si bien la fusta se asemeja más a la de un oficial de caballería (2001: 28).

Otro tipo de atuendo identificativo, si bien más luctuoso, fue el uniforme carcelario. Las activistas supieron sacar también rendimiento a este diseño en un alarde de equiparación estética. El corpus fotográfico de las sufragistas encarceladas, sobre todo en la temible prisión de 
mujeres de Holloway, en Islington (Londres), muestra unas austeras prendas oscuras y delantales y cofias blancas, con unas puntas de flecha sobreimpresas que la prisión obligó a llevar como símbolo carcelario. El uniforme impuesto por las instituciones penitenciarias para escarnio de estas mujeres, también fue hábilmente utilizado fuera de la prisión, reconvirtiendo el escarnio en empoderamiento. Entre los más utilizados estaban estas puntas de flecha que adoptan la forma de broches $\mathrm{O}$, a mayor tamaño, se blandían en las manifestaciones; también crearon accesorios y estandartes a partir de elementos carcelarios unidos: el enrejado de los ventanucos de la cárcel al que se aplicaban cadenas y las puntas de flecha con el emblema tricolor. En los encuentros públicos, muchas mujeres excarceladas seguían vistiendo el uniforme de prisión en recuerdo y homenaje de las compañeras que continuaban presas o para visibilizar las vejaciones sufridas.

La intensa actividad manual textil con que las sufragistas se lanzan a la conquista de los espacios públicos tiene en las banderas y los pañuelos bordados algunos de sus productos más significativos y elaborados (Parker, 1984: 197-198). La mayor parte de ellas salieron del Atelier ya nombrado, por lo que, a diferencia de las realizadas para los sindicatos por empresas profesionales contratadas para tal fin, el trabajo sufragista tuvo un carácter de mayor implicación femenina, mediante la estimación de la capacitación personal de las mujeres, puesta al servicio de la causa. En este sentido, la actividad textil, bien realizada por bordadoras profesionales, bien como labor doméstica asociada a las mujeres de toda edad y clase social en la intimidad del hogar y para el hogar, se redimensionaba adquiriendo una trascendencia política. De hecho, la utilización del bordado era plenamente intencionado dentro del programa activista. Los productos creados unían en muchas ocasiones el trabajo textil, con la pintura y las aplicaciones, lo que ponía en evidencia un interés consciente por valorar las capacidades femeninas, subestimadas a un rango inferior, artesanal y no artístico, para combinar técnicas y formatos artísticos distintos, creando sensaciones plásticas, valorando la calidad y posibilidades de los materiales y demostrando un conocimiento especializado de las dificultosas técnicas del bordado profesional (Parker, 1984: 198-199).

Los lemas bordados en las banderas atendían a diferentes objetivos: identificar a los grupos locales, representar colectivos profesionales, enarbolar campañas reivindicativas, declarar principios y estimular con frases y palabras sencillas y directas de gran impacto y ágil recuerdo y repetición - «Deeds, no words», «No Vote no Tax», «Dare to be free», «Ask with Courage», «Consistency», «Rectitude» «Success»-; O conmemorar y homenajear a grandes mujeres del pasado y del presente, como la reina celta Boadicea, la Reina Victoria, las hermanas Brontë, Elizabeth Barrett Browning o Marie Curie, entre otras, es decir, mujeres ejemplares en distintos planos, del poder, la creación artística y literaria o la ciencia, cuya excelencia estaba apoyada en el esfuerzo, la constancia, la voluntad y la fuerza. 
También formaba parte de los objetivos de todo el trabajo creativo el homenaje a mujeres sufragistas tenidas como referentes. Una de las banderas conmemorativas de la WSPU recoge los nombres bordados de las sufragistas fundadoras del movimiento y activistas más combativas que habían sido torturadas en la cárcel, principalmente con la terrible alimentación forzada (fig. 8). La bandera organiza la composición en una sencilla y ordenada cuadrícula, enmarcada por una orla de tela, en la que cada seguidora deja constancia de su admiración, bordando su propio nombre con caligrafías de diversa calidad, reforzando el carácter participativo y colaborativo de la acción. Esta pieza es una muestra fehaciente de la trascendencia de este tipo de trabajo en el seno de los discursos canónicos del arte, al no hacer distinciones entre arte y artesanía, al combinar alta cultura y referencias a los estilos artísticos consagrados -los nombres de las cuatro homenajeadas aparecen en un cuidado bordado art nouveau- con la naturaleza manual, directa y sencilla de las caligrafías. De alguna manera, esta fórmula se anticipa al método utilizado por el movimiento «bordando contra los feminicidios», como veremos más adelante.

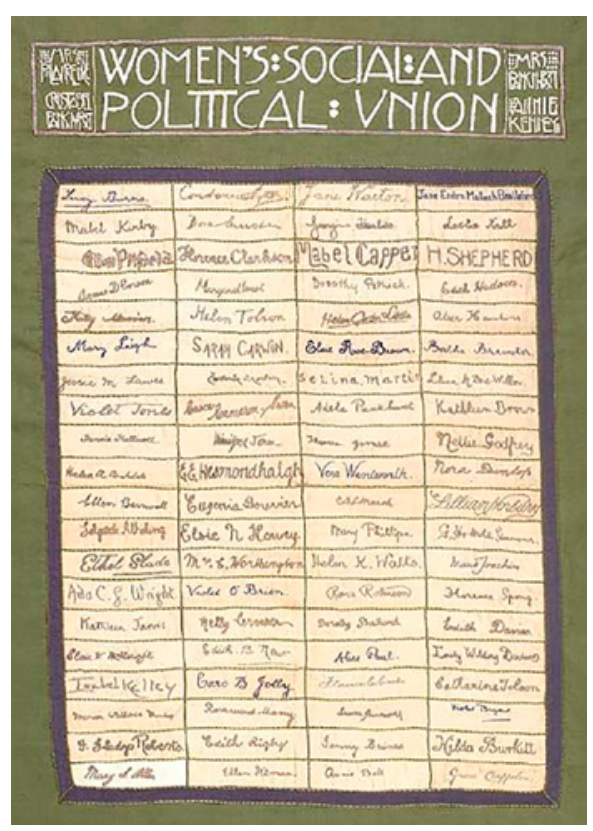

Fig. 8. Bandera conmemorativa WSPU, 1910. Fuente: Museum of London.

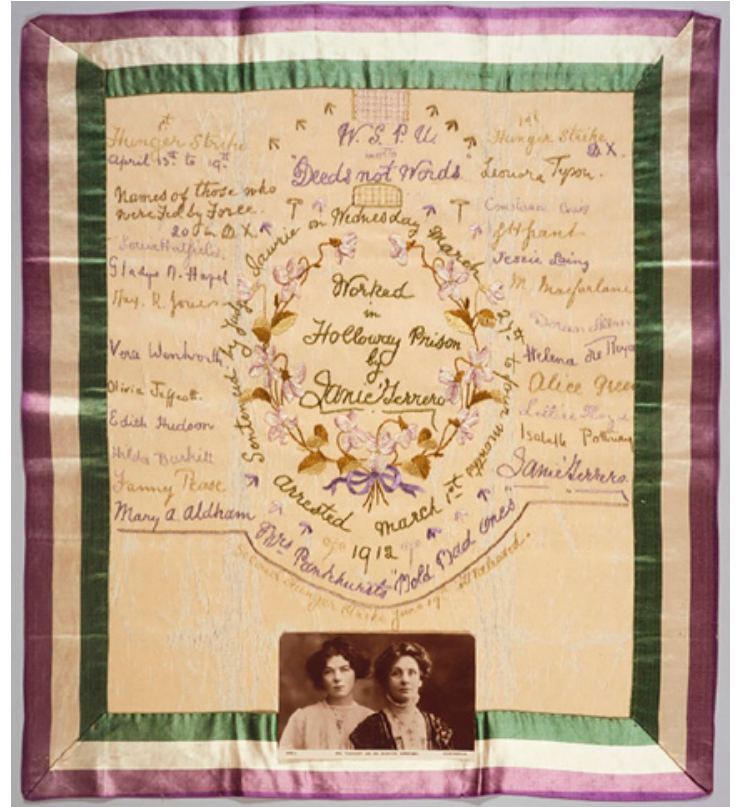

Fig. 9. Janie Terreno, pañuelo sufragista, 1911. Fuente: Museum of London. 
La actividad textil en prisión abarcaba también una dimensión económica expresa, de modo que el Estado se aprovechaba de las habilidades manuales textiles de las mujeres que debían, entre otras cosas, coser bolsas de correos (fig. 6).

Pero también para estas activistas, privadas de libertad, en huelga de hambre y torturadas, estas labores podían llegar a ofrecer propiedades terapéuticas. La sufragista Janie Terreno firma un pañuelo bordado para recordar la huelga de hambre de 1911 (Parker, 1984: 200-201) (fig. 9); la confección se organiza con la cinta tricolor cosida a modo de orla, solo interrumpida por la fotografía de Emmeline Pankhurst y su hija Christabel, pegada en el borde inferior, a quienes se rinde tributo; en el centro, la firma de la autora, orlada de violetas primorosas, deja constancia de esa autoría y de la iniciativa laudatoria, que refrendan los nombres de las compañeras; completan la composición los atributos sufragistas más identificativos: el lema «deeds, not words», el enrejado carcelario y las puntas de flecha. Este pañuelo sufragista, trabajado a modo de collage en su combinación de técnicas, costura, aplicaciones, bordado, texturas, materiales y colores, texto e imagen, desafía de nuevo el paradigma artístico.

En los productos creados por estas mujeres mediante las diferentes técnicas textiles se aprecia también la intención de moldear las figuras de las líderes, lo que lleva a plantearnos el concepto de la heroicidad en el seno del sufragismo (Parker, 1984). No obstante, trasciende el movimiento para instalarse en el seno de los estudios feministas, a través de temas tales como la ausencia de referentes, la necesidad de crear genealogías, o el cuestionamiento de la personalidad del genio. Creo que indagar en estos comportamientos puede ayudar a posicionar otros planteamientos críticos que vinculen estas prácticas de mujeres no profesionales del arte con algunas obras de artistas mujeres profesionales y que usan medios similares. Estoy pensando en el trabajo de Judy Chicago y la conocida, estudiada y criticada The Dinner Party (1974-1979) y sus aparentes contradicciones entre anonimato y autoría, trabajo femenino autónomo e individual y colectivo, manualidad artesanal y espectáculo visual o culto a la heroicidad femenina y el silencio o la invisibilidad.

\section{Bordar contra el feminicidio}

En el seno del proyecto «Bordando por la paz»", que surgió en Ciudad de México, se inicia el movimiento «Bordando feminicidios», que comienza a bordar el 23 de diciembre de 2012 y continúa activo. El primer colectivo, bajo el lema «un pañuelo, una víctima», se

7 Vinculado al colectivo Fuentes Rojas de Ciudad de México. Todos los colectivos nombrados disponen de perfil en las redes sociales. Son numerosos los artículos periodísticos en los que se resume la trayectoria y objetivos del proyecto «Bordando por la paz». Destacan, entre otros, Montero (2012) y Rizzo (2015). 
propone visibilizar y homenajear a los cuantiosos asesinados y desaparecidos durante los gobiernos de Felipe Calderón y de Peña Nieto, en el marco de la guerra contra el narcotráfico. No obstante, las víctimas de feminicidio, por su propia idiosincrasia, necesitaban de un activismo específico, que, al mismo tiempo, respondiera a la imprescindible localización y focalización de los casos y las acciones. Para ello, el código visual, que para el grupo genérico distinguía el rojo para los muertos y el verde para los desaparecidos, retoma el cromatismo feminista distintivo en violeta y tonos morados.

«Bordando feminicidios» ${ }^{8}$ carece de un decálogo programático, puesto que efectivamente no tiene carácter asociacionista expreso. Sin embargo, sus inquietudes y motivaciones son poderosas y afectan no solo a las mujeres masacradas destinatarias de los bordados, sino también a las mujeres que bordan. El bordado, en opinión de algunas de las activistas iniciadoras de la experiencia9, permite ante todo la reflexión pausada, puesto que, independientemente de la calidad o la habilidad, aspectos estos insignificantes, la labor ralentiza el tiempo, puntada tras puntada. Este depositar el pensamiento supone devolver la memoria y la identidad a tantas mujeres masacradas, ignoradas y olvidadas o inexplicablemente desconocidas, que son únicamente expedientes para las instituciones, e incluso para los medios de comunicación. En los pañuelos, cada caso feminicida cobra actualidad y vida ${ }^{10}$. A través de la elaboración de la prenda, se les devuelve la palabra a las mujeres asesinadas, puesto que siempre el texto se redacta en primera persona; diversos pormenores sobre quiénes eran activa y recuerda sus identidades y sus vidas, mientras el relato de las torturas y asesinatos, y las fechas, denuncian lo sufrido y ancla a una realidad cotidiana; en ocasiones, las palabras se acompañan de elementos figurativos vinculados a sus gustos -detalles de un tatuaje, flores, estrellas, etc.-; pero también los pañuelos bordados denuncian a los feminicidas, cuyos nombres aparecen escritos con lápiz o tachados una vez bordados, en un acto simbólico y físico a la vez -se emplea otro material o un hilo superpuesto- y de doble recorrido: la evidencia, en contra de la impunidad, y la anulación del asesino. Por su parte, la firma de la bordadora establece un vínculo entre las dos mujeres

\footnotetext{
8 lgualmente son numerosas las vías divulgativas sobre la trayectoria del colectivo, los objetivos y el carácter de las acciones. Las actividades de bordado, en expansión por numerosos países, generan una gran cantidad de notas informativas y artículos de opinión. Además de la página de Facebook (https://www.facebook.com/bordamos.feminicidios/), con la cual se puede estar al día y contactar para sumarse a las experiencias bordadoras, son muy útiles, principalmente, el artículo de Fabré y León (2017), y las entrevistas escritas o audiovisuales a miembros del colectivo; Villafranca I y II (2013) ofrece un recorrido más resumido.

9 Marcela Valenzuela y Yuriria Rodríguez ofrecen una inestimable información en la extensa entrevista «Bordamos feminicidios», realizada en el programa Luchadoras. Rompeviento TV. 20/2/13 (https://www.youtube.com/watch? $v=x E R r e U e-k P g)$.

10 Se ha elaborado una base de datos que se nutre fundamentalmente del Observatorio Ciudadano Nacional del Feminicidio, red de 49 asociaciones de colectivos y asociaciones de mujeres que documentan los casos y a la cual se puede acceder desde la página de Facebook.
} 
que se han prestado la voz y la palabra, que se reconocen en las vivencias y en la experiencia de ser mujeres (fig. 10).

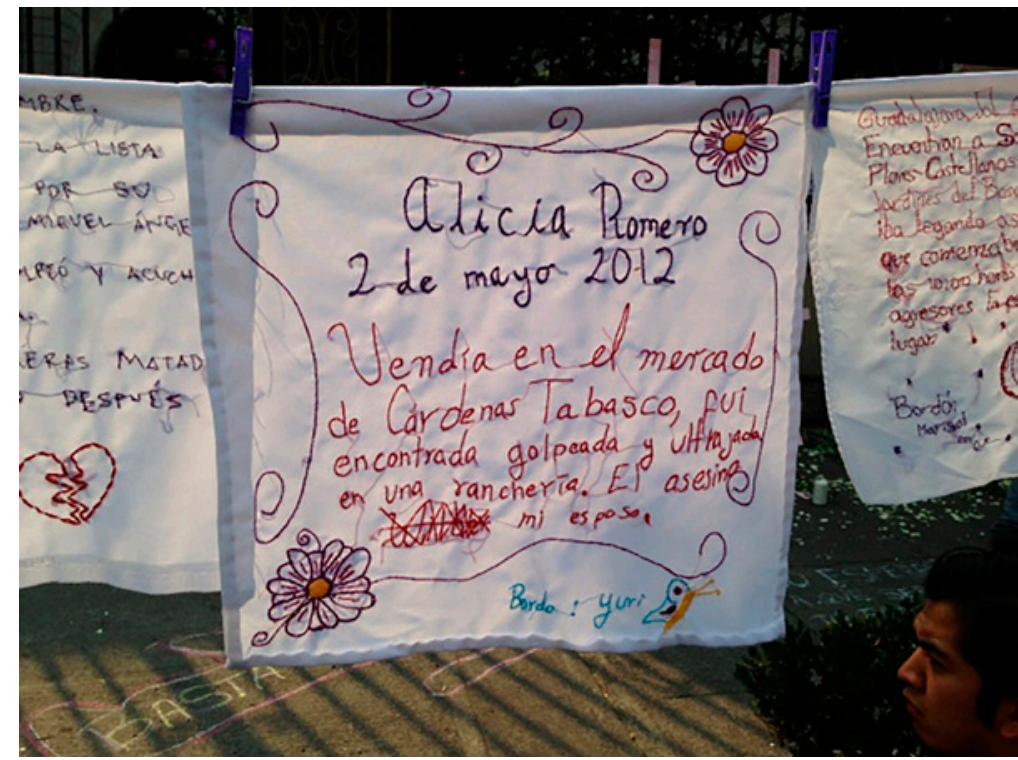

Fig. 10. Pañuelo bordado. Fotografía: Paula Chouza. Fuente: http://blogs.elpais.com/periscopiochilango/2013/04/bordar-feminicidios-para-buscar-la-paz-1.html.

Una acción para la memoria y la justicia -aunque una justicia que no debería suplir nunca las obligaciones de las autoridades- pero que parte de la realidad del desamparo, de la impotencia de la impunidad, y de la criminalización y culpabilización de las mujeres. No son crímenes pasionales, ni producto del crimen organizado, porque, como observa Yuriria Rodríguez ${ }^{11}$, los feminicidios son consecuencia de la misoginia y la discriminación.

El tiempo de las experiencias truncadas, con sus historias vividas, quiénes eran estas mujeres y cómo fueron torturadas y asesinadas, traslada el sentido de los pañuelos, desde que sirvieron como sudarios, o para enjugar las lágrimas ante la pérdida y la desesperación, hasta convertirse en soportes de vida, estímulos de la evocación y vehículos de denuncia pacífica. «Empezamos pensando que fuera una denuncia - declara Minerva Valenzuela-, pero finalmente dejó de ser solo eso para convertirse en el acto maravilloso de mujeres vivas, juntas, bordando,

11 Miembro del Observatorio Ciudadano Nacional del Feminicidio y bordadora del colectivo. Esta observación está tomada de la entrevista en el programa de televisión mencionado. 
conociéndonos, mirándonos a los ojos, aprendiendo sobre violencia, feminicidio, machismo y evidentemente, haciendo del feminismo algo mucho más cercano a nosotras» ${ }^{12}$.

La construcción de la memoria colectiva y la implicación de las mujeres tiene que ver también con la forma de abordar la acción y de compartirla. La sororidad se perfila ante la fortaleza de las mujeres que se unen para bordar, que aprenden juntas y toman conciencia del valor de saberse responsables de la visibilización de los feminicidios y de desvelar el carácter de los mismos. Y esto permite y potencia el empoderamiento: «reconocernos y hacer una cadena expansiva», comentan las activistas. La labor de bordado adquiere entonces diversas dimensiones. Por un lado, se puede realizar en solitario y en cualquier lugar o situación, mientras se viaja en el transporte público, haciendo cola, o en el hogar. Esto provoca una llamada de atención en otras personas que se interesan por lo que hacen las bordadoras, suscitando la posibilidad del conocimiento y la empatía con lo que ocurre, así como una toma de conciencia. También puede desarrollarse en un espacio privado pero compartido, en reuniones en las casas o mientras se conversa. De esta manera, las mujeres asesinadas y sus historias comparten los espacios y las experiencias cotidianas de las bordadoras. Sin olvidar que periódicamente las acciones se llevan a cabo en los espacios públicos a través de convo-

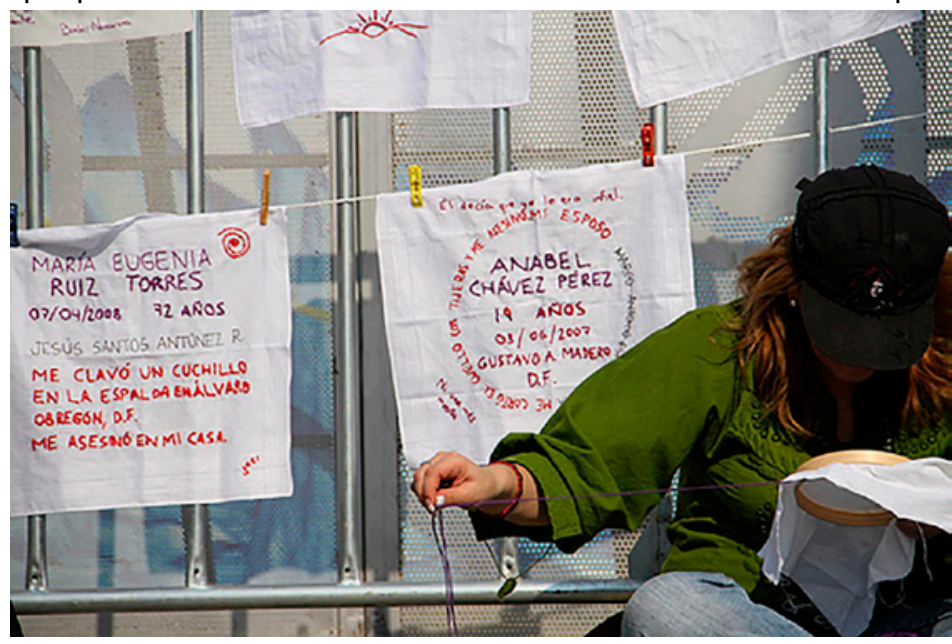

Fig. 11. Bordadera colectiva de «Bordamos Feminicidios» en el Zócalo, 15 de diciembre 2012. Fuente: https://www.flickr.com/photos/produccionesymilagros/sets/72157632270294704/ catorias programadas (fig. 11). Por tanto, se permite un trasvase de significación entre lo privado y lo públi$\mathrm{co}$, entre lo que permanece callado y desconocido y lo que debe responsabilizar e implicar a toda la sociedad. «El tejido social que se ha roto, aquí tratamos de volverlo a tejer, así como la aguja entra en el pañuelo, las historias entran y restauran un poquito de lo roto», comenta Minerva Valenzuela ${ }^{13}$.

12 Minerva Valenzuela es actriz, cabaretera y activista por los derechos sexuales, y bordadora del colectivo. Esta referencia proviene de la entrevista publicada en Nación (2013).

13 Entrevistada por Irma Gallo (2017). 
Pero bordar con este sentido terapéutico y reivindicativo hace referencia también a otra realidad que tiene que ver con la explotación del trabajo femenino en las distintas fases del trabajo textil. Bordar es el trabajo extenuante y mal pagado que emplea a miles de mujeres y niñas sin derechos laborales (en ocasiones a familias enteras) en algunos países latinoamericanos. Es el caso de las mujeres bordadoras a domicilio de El Salvador que trabajan desde sus casas para empresas maquiladoras ${ }^{14}$ o de las numerosas mujeres empleadas por la industria de la maquila en numerosas ciudades mexicanas, tristemente conocidas por el índice de feminicidios. De alguna manera, la acción contra-feminicida escoge una profesión eminentemente femenina, esencial empresarialmente y sin embargo infravalorada, en la que no se respetan los más elementales derechos.

Por todo ello, los bordados contra-feminicidas funcionan como auténticas «intervenciones estético-políticas», junto a otras acciones como las cruces rosas, las performances políticas y los escraches:

El performance como quiebre de la cotidianidad, y para muchas mujeres el performance como un quiebre subjetivo: en donde ellas -las vivas («vivas nos queremos») y las aparecidas («aquí estamos»)- narran en primera persona testimonios de aquellas a quienes les han arrebatado el derecho a la vida, el derecho al cuerpo» (Fabré y León, 2017).

De este modo, se redimensiona el poder estético-político y simbólico de la acción y de sus resultados: se trabaja en una labor colaborativa, sea en solitario o en grupo, se conversa, se comparte, se visibiliza una tarea de paz en lugares cotidianamente muy violentos y peligrosos para las mujeres, cuyos cuerpos vivos han sido masacrados y expulsados para luego ser devueltos como despojos, violentados, torturados y asesinados. Es decir, la acción subvierte el sentido de la violencia en claves pacíficas y lo hace mediante una actividad asociada a los espacios domésticos y a las propias mujeres.

Se efectúa de esta forma una profunda transformación de los espacios públicos secuestrados, a pesar de la aparente sencillez e intrascendencia de las intervenciones (fig. 12). Calles y plazas se tornan territorios en lucha en los que, paradójicamente, se llevan a cabo actividades cotidianas, que parte de las mujeres y retorna a ellas. Tejer en la calle desenmascara entonces las fronteras y dicotomías construidas por el paradigma patriarcal, y lo hace al subvertirlas o al ignorarlas: no solo las esferas de lo público y

\footnotetext{
14 Algunas de estas mujeres se están movilizando y agrupando. "Mujeres Transformando» es una organización feminista creada para defender esos derechos, organizar a las obreras y crear una cultura de respeto de los derechos humanos (Arévalo, 2015). Una de las acciones que forman parte de la campaña "Haciendo visible lo invisible: la realidad de las bordadoras a domicilio», impulsada por esta organización es la obra de teatro Made in El Salvador. De bordar en bordar se me fue la vida..., creada por la compañía Teatro del Azoro.
} 
lo privado, sino también las distancias entre arte y artesanía, entre profesionalidad y domesticidad $^{15}$.

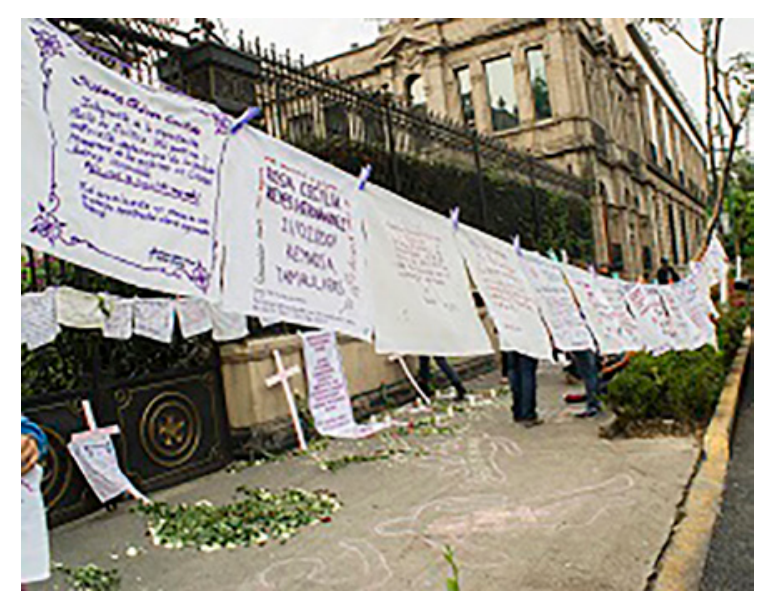

Fig. 12. Pañuelos y cruces. Colectivo «Bordamos feminicidios». Fotografía: Mayela Sánchez.

Fuente: https://globalpressjournal.com/americas/mexico/embroidery-collective-gives-voice-to-mexico-s-victims-of-gender-based-killings/

Para Fabré y León (2017) los espacios en lucha son una extensión -podríamos decir que un trasunto- de los propios cuerpos de las mujeres. «Recuperando a las feministas comunitarias se asume, entonces, a los cuerpos como el primer lugar de enunciación: nuestro cuerpo de mujeres como nuestro primer territorio a recuperar y defender». Y continúan:

Porque en un país en donde los cuerpos de las mujeres son asumidos como desechables, la idea del cuerpo-territorio puede ayudar a dimensionar los significados en torno a diversas acciones colectivas, especialmente aquellas en las que hay una apropiación de espacios de poder. ¿̇A qué nos referimos con esto? A la ocupación de los lugares en donde la violencia contra las mujeres se produce de manera tal que parece un territorio perdido (Fabré y León, 2017).

De ahí que no exista otro camino que el de la autorreferencialidad, que es el que conduce a la autodeterminación ${ }^{16}$. El silencio y el olvido se transmutan en los textos e imágenes

\footnotetext{
15 No obstante, estas acciones, desprovistas de profesionalización en la esfera artística propiamente dicha, convoca también a artistas que han incorporado estas experiencias a sus obras. Es el caso, entre otras, de la mexicana Rosa Borrás (Querido Diario, 2015) o de la norvega Lise Bjorn (Desconocida, Museo de la Mujer de Ciudad Juárez); también, la sensibilización del colectivo de artistas miembros de Fiber Art Fever, que trabajan el textil contemporáneo. Al mismo tiempo, se han generado exposiciones en las que las bordadoras de feminicidios han participado, como «La trama activa. Tejidos e implicación social», celebrada en 2015 en el Museo Casa Caravati (San Fernando del Valle de Catamarca, Argentina), una muestra de arte contemporáneo con artistas locales y extranjeros.

16 He trabajado la autodeterminación en el ámbito de la imaginería de mujeres escritoras (Ruiz Garrido, 2017: 105-131).
} 
en voz y memoria, presentes en la acción bordadora de las mujeres. La violencia contra los cuerpos (Ballester, 2012) se restituye con la palabra que narra y denuncia.

\section{Referencias}

Arévalo Alvarado, Montserrat (27 de enero de 2015). "Made in El Salvador. De bordar en bordar se me fue la vida» en Amecopress. Información para la igualdad. Recuperado en http://www.amecopress.net/spip.php?article 12004.

Ballester Buigues, Irene (2012). El cuerpo abierto. Representaciones extremas de la mujer en el arte contemporáneo, Gijón: Ediciones Trea.

Bordamos feminicidios, en Luchadoras. Rompeviento TV. 20/2/13. Recuperado en https:// www.youtube.com/watch? $v=x E R r e U e-k P g$.

CHADWICK, Whitney (1992). Mujeres, arte y sociedad. Trad. María Barberán, Barcelona: Ediciones Destino.

Chouza, Paula (10 de abril de 2013). «Bordar feminicidios para buscar la paz» en El País. Blog internacional. Recuperado de http://blogs.elpais.com/periscopiochilango/2013/04/bordar-feminicidios-para-buscar-la-paz-1.html.

CLARK, Toby (2001). Arte y propaganda en el siglo XX. Trad. Isabel Balsinde, Madrid: Akal.

DeEPWELl, Katy (ed.). Nueva crítica feminista de arte. Estrategias críticas. Trad. María Condor, Madrid: Cátedra / Universidad de Valencia.

DUKSTRA, Bram (1986). Ídolos de perversidad. La imagen de la mujer en la cultura de fin de siglo. Trad. Vicente Campos Fernández, Madrid/Barcelona, Debate/Círculo de Lectores, 1994.

FABRÉ NADAL, Helena y LEÓN, Ana Karen (10 de diciembre de 2017). «Feminicidios: la imagen del horror» en La jornada semanal. $N^{\circ} 1188$. Recuperado de http://semanal. jornada.com.mx/2017/12/10/feminicidios-la-imagen-del-horror-1385.html.

FederICl, Silvia (2004). Calibán y la bruja. Mujeres, cuerpo y acumulación originaria. Trad. Verónica Hendel y Leopoldo Sebastián Touza, Madrid: Traficantes de sueños.

GALLO, Irma (noviembre 2017). «Bordar contra el olvido» en Revista Cambio. Recuperado de http://www.revistacambio.com.mx/nacion/bordar-contra-el-olvido/.

GonZÁlez HeRNÁNDEZ, María Jesús (2009). «Las sufragistas británicas y la conquista del espacio público: integración, recreación y subversión» en Arenal. № 16, Vol. 1, pp. 53-84.

MONTERO, Martha Patricia (5 de diciembre de 2012). «Bordar por la paz: la herida en un pañuelo» en Sinembargo.mx. Recuperado de http://www.sinembargo.mx/05-12-2012/449678.

Nead, Lynda (1992). El desnudo femenino. Arte, obscenidad y sexualidad. Trad. Carmen González Marín, Madrid: Tecnos, 1998. 
PARKER, Rozsika (1984). The subversive stitch. Embroidery and the making of the feminine, Londres: The Women's Press.

Parker, Rosiska y Pollock, Griselda (1981). Old Mistresses: Women, Art and Ideology, Londres: I. B. Tauris, 2013.

PICAZO GuRINA, Marina (2008). Alguien se acordará de nosotras. Mujeres en la ciudad griega antigua, Barcelona: Edicions Bellaterra.

Pollock, Griselda (1988). Visión y Diferencia. Feminismo, feminidad e historias del arte. Trad. Azucena Galettini, Buenos Aires: Fiordo, 2013.

Pollock, Griselda (1999). «Diferenciando: el encuentro del feminismo con el canon» en CoRdero, Karen y SÁENZ, Inda (comps.) (2007). Crítica feminista en la teoría e historia del arte, Ciudad de México: Universidad Iberoamericana, pp. 141-158.

Rızzo, Cordelia (2015). «La red que se teje fuerte: 4 años de bordar por La Paz» en Hysteria. $N^{\circ}$ 13. Recuperado de http://hysteria.mx/laredquesetejefuerte/.

Ruiz GarRIDO, Belén (2017). "'Escribe o date por perdida'. Imágenes de escritoras en la creación artística contemporánea» en MÉNDEZ BAIGES, Maite (ed.) (2017). Arte escrita. Texto, imagen y género en el arte contemporáneo, Granada: Comares, pp. 105-131.

TICKNER, Lisa (1987). The Spectacle of Women: Imagery of the Suffrage Campaign 1907-14, Londres: Chatto \& Windus.

TRASFORINI, Maria Antonietta (2009). Bajo el signo de las artistas: mujeres, profesiones de arte y modernidad, Valencia: Universidad de Valencia.

VillafRANCA, David (31 de mayo de 2013). «Bordados y cruces contra los feminicidios (I)» en HemisferioZero. Recuperado de http://hemisferiozero.com/2013/05/31/ bordados-y-cruces-contra-los-feminicidios-i/.

_ (12 de junio de 2013). «Bordados y cruces contra los feminicidios (II)» en HemisferioZero. Recuperado de http://hemisferiozero.com/2013/06/12/bordados-y-cruces-contralos-feminicidios-ii/. 